\title{
PENGARUH MATHEMATICAL BELIEFS TERHADAP PRESTASI BELAJAR MATEMATIKA SISWA SMA
}

\author{
Ratri Isharyadi*1, Hera Deswita ${ }^{2}$ \\ ${ }^{1,2}$ Program Studi Pendidikan Matematika, Fakultas Keguruan dan Ilmu Pendidikan, \\ Universitas Pasir Pengaraian, Rokan Hulu, Riau \\ e-mail: *19arya math@ymail.com
}

\begin{abstract}
Abstrak. Penelitian ini bertujuan untuk mengetahui pengaruh mathematical beliefs terhadap prestasi belajar matematika siswa SMA. Mathematical beliefs merupakan keyakinan siswa terhadap matematika. Pada penelitian ini akan dilihat bagaimana beliefs siswa pada pendidikan matematika, yaitu: beliefs siswa terhadap matematika dan beliefs siswa terhadap masalah matematika. Penelitian ini adalah penelitian deskriptif korelasional menggunakan pendekatan kuantitatif. Sumber data penelitian ini adalah siswa kelas XII IPS 2 di SMAN 1 Rambah. Data yang dikumpulkan adalah data tentang mathematical beliefs melalui instrumen angket dan data hasil belajar matematika siswa. Data hasil penelitian dianalisis menggunakan analisis korelasi dan regresi untuk mengetahui besar pengaruh dan hubungan mathematical beliefs terhadap hasil belajar matematika siswa SMA. Seluruh proses analisis data dibantu dan memanfaatkan Microsoft office excel 2013 dan program komputer SPSS 20.0 for Windows. Hasil penelitian menunjukkan bahwa tidak terdapat pengaruh yang signifikan mathematical beliefs terhadap prestasi belajar matematika siswa.
\end{abstract}

Kata kunci: Mathematical beliefs, matematika, prestasi belajar.

\begin{abstract}
This study aims to determine the effect of mathematical beliefs towards mathematics achievement of high school students. Mathematical beliefs are beliefs of students towards mathematics. This research will be seen how the beliefs of students towards mathematics drawn from students' beliefs towards mathematics as a subject, and beliefs in math problems. This study is descriptive correlational research using quantitative approach. The data source of this research is the students in a class at SMAN 1 Rambah. The data collected is data about mathematical beliefs through questionnaires and data of students' mathematics learning. Data were analyzed using correlation and regression analysis to determine the influence and mathematical beliefs relationship to the student' mathematics achievement. The whole process is assisted data analysis using Microsoft Office Excel 2013 and SPSS 20.0 for Windows. The results showed that there was no significant effect of mathematical beliefs towards mathematics achievement of students.
\end{abstract}

Keywords: Mathematical beliefs, mathematics, learning achievement.

\section{Pendahuluan}

Kemampuan siswa dapat dilihat dari beberapa segi, seperti kemampuan kognitif, afektif, maupun psikomotorik. Ketiga kemampuan tersebut tentu memiliki kontribusi yang berbeda pada kehidupan siswa. Ketiga kemampuan itu pula merupakan komponen penting yang dapat membawa siswa kemana minat siswa dimasa depan. Salah satu kemampuan afektif yang penting adalah beliefs siswa terhadap matematika. Hal ini diungkapkan berdasarkan hasil penelitian Shoenfeld (1989), Mc Leod (1992), dan Cobbs (1986) (Eleftherios \& Theodosios, 2007:97) yang menyatakan bahwa terdapat hubungan antara beliefs dengan kinerja matematika siswa, artinya hasil-hasil belajar siswa berhubungan erat dengan beliefs siswa terhadap matematika. 
Kata belief berasal dari bahasa inggris yang artinya kepercayaan atau keyakinan. Belief, dalam kamus Oxford, diartikan sebagai: (1) Penerimaan bahwa sesuatu ada atau benar, terutama yang tanpa bukti, (2) Perasaan yang kuat tentang keberadaan sesuatu, (3) Percaya bahwa sesuatu itu baik atau benar. Dalam bahasa sehari-hari, istilah "keyakinan" atau belief sering disamaartikan dengan istilah sikap (attitude), disposisi (disposition), pendapat (opinion), filsafat (philosopy), atau nilai (value).

Spangler (1992: 19) menyatakan bahwa terdapat hubungan antara keyakinan dengan belajar. Pengalaman belajar siswa mungkin berkontribusi terhadap keyakinan mereka tentang apa artinya untuk belajar matematika. Pada gilirannya keyakinan siswa tentang matematika cenderung mempengaruhi bagaimana mereka mendekati pengalaman matematika yang baru. Kloosterman (1992: 109) menyatakan bahwa meningkatkan beliefs siswa terhadap matematika seringkali dapat meningkatkan motivasi mereka terhadap belajar matematika dan akhirnya dapat meningkatkan hasil belajar mereka. Pembelajaran matematika dipengaruhi oleh motivasi, sedangkan motivasi merupakan hasil dari belief mengenai matematika sebagai subjek (mata pelajaran), belief mengenai diri sendiri sebagai pembelajar, belief mengenai peran guru matematika dan belief lain mengenai pembelajaran matematika.

Menurut NCTM (2000: 76) untuk membangun keyakinan yang solid tentang matematika, siswa harus mengetahui tentang arti matematika dan kepercayaan siswa dalam menggunakan matematika. Keyakinan ini mempengaruhi cara berpikir, kinerja, sikap, dan pengambilan keputusan siswa tentang studi matematika di tahun-tahun berikutnya. Sehingga penilaian beliefs siswa tentang matematika dapat membantu guru merencanakan instruksi dan struktur lingkungan kelas sehingga dapat membantu siswa mengembangkan keyakinan lebih tercerahkan tentang matematika dan belajar matematika.

Beliefs siswa menggambarkan keyakinan subjektif siswa, hal ini dilihat dari seberapa baik siswa melakukan matematika dalam kehidupannya dan bagaimana peran individu dalam mengembangkan keterampilan dan kompetensi matematika. Berdasarkan kinerja siswa yang diperoleh sebelumnya, beliefs siswa mempengaruhi bagaimana fungsi siswa ketika berhadapan dengan masalah matematika, dan bagaimana siswa memilih dan memutuskan sesuatu dalam hidupnya (OECD, 2013: 81). Beliefs dalam matematika menurut Schoenfeld (De Corte \& Eynde, 2002: 96) dapat menentukan bagaimana memilih satu pendekatan untuk menyelesaikan masalah, teknik yang akan digunakan atau dihindari, berapa lama menyelesaikan masalah dan seberapa keras usaha yang dilakukan, dan sebagainya.

Schoenfeld (Kaur, 1997:104) menyatakan bahwa sikap terhadap matematika dan keyakinan tentang matematika mungkin memiliki efek yang penting pada bagaimana siswa mengelola kemampuan kognitif mereka. Hal ini memperkuat pendapat bahwa beliefs siswa terhadap metematika memiliki hubungan dengan kemampuan kognitif siswa. Matematika masih dianggap sebagai mata pelajaran yang sulit bagi siswa. Anggapan tesebut merupakan beliefs siswa yang terbangun melalui pengalaman yang mereka peroleh ketika belajar matematika. Greer, Verscaffel, dan De Corte (Sugiman, 2010) menyatakan bahwa keyakinan seorang siswa dipengaruhi oleh faktor guru, buku teks, strategi pembelajaran dan pemanfaatan masalah-masalah yang terdapat disekitar siswa dalam kegiatan pembelajaran. Hal ini sejalan dengan yang diungkapkan oleh Spangler (1992:19) yang menyatakan bahwa jenis pembelajaran matematika dapat memberikan pengalaman matematika yang akan memperkaya keyakinan siswa tentang matematika. Mengingat pentingnya beliefs matematis 
siswa, perlu dilihat bagaimana beliefs awal siswa terhadap matematika untuk selanjutnya dapat dilakukan pembelajaran yang dapat menunjang beliefs matematis siswa yang baik. Pada penelitian ini dilihat bagaimana beliefs siswa pada pendidikan matematika, yaitu: beliefs siswa terhadap matematika dan beliefs siswa terhadap masalah matematika.

Proses belajar merupakan salah satu faktor yang dapat membangun beliefs siswa. Belajar merupakan kegiatan bagi setiap orang. Pengetahuan keterampilan, kebiasaan, kegemaran dan sikap seseorang terbentuk, dimodifikasi dan berkembang disebabkan belajar. Karena itu, seseorang dikatakan belajar, bila dapat diasumsikan dalam diri orang itu menjadi suatu proses kegiatan yang mengakibatkan suatu perubahan tingkah laku (Hudojo,1990). Belajar adalah proses perubahan tingkah laku berkat pengalaman dan latihan (Djamarah, 2006). Belajar adalah merupakan proses yang ditandai dengan adanya perubahan pada diri seseorang (Sudjana, 2010). Sehingga dari beberapa pendapat ahli tersebut, dapat kita simpulkan bahwa belajar merupakan suatu proses yang dilakukan untuk mendapatkan perubahan tingkah laku pada diri seseorang.

Menurut Kamus Besar Bahasa Indonesia, matematika adalah ilmu tentang bilanganbilangan, hubungan antar bilangan, dan prosedur operasional yang digunakan dalam penyelesaian masalah mengenai bilangan. Namun, kalau kita telaah, matematika tidak hanya berhubungan dengan bilangan-bilangan serta operasi-operasinya, melainkan juga unsur ruang sebagai sasarannya (Hudojo, 1990). Sasaran penelaahan matematika tidaklah konkrit, tetapi abstrak. Sehingga secara singkat dapat dikatakan bahwa matematika berkenaan dengan ideide atau konsep-konsep abstrak yang tersusun secara hirarkis dan penalarannya deduktif (Hudojo, 1990). Dari pengertian belajar dan matematika tersebut, dapat kita simpulkan bahwa belajar matematika merupakan proses yang dilakukan untuk memperoleh perubahan berupa pengetahuan matematika pada diri seseorang. Salah satu tujuan belajar matematika pada jenjang pendidikan dasar dan menengah adalah agar siswa memiliki kemampuan memahami konsep matematika dan mengaplikasikan konsep matematika dalam pemecahan masalah (Permendiknas No.22 Tahun 2006).

Setelah siswa belajar matematika, diharapkan siswa mampu mendemontrasikan keterampilan matematika dari sebelumnya yang tidak dapat dilakukannya. Perubahan pengetahuan tersebut merupakan hasil dari belajar yang telah dilakukan oleh siswa. Prestasi belajar matematika merupakan tampilan pemahaman dan penguasaan terhadap materi matematika yang telah dipelajari siswa (Hudojo, 1990). Penilaian hasil belajar, termasuk mata pelajaran matematika oleh guru terdiri atas ulangan harian, ulangan tengah semester, ulangan akhir semester dan ulangan kenaikan kelas. Ulangan harian merupakan kegiatan yang dilakukan oleh guru secara periodik untuk menilai atau mengukur pencapaian kompetensi setelah menyelesaikan satu kompetensi dasar atau lebih (Permendiknas No.20 Tahun 2007). Prestasi belajar yang dimaksud pada penelitian ini adalah tingkat ketuntasan belajar matematika berdasarkan skor ulangan harian setelah siswa mengikuti proses pembelajaran matematika.

Berdasarkan penelitian tentang mathematical beliefs telah ditemukan bukti bahwa terdapat hubungan antara peran dan fungsi guru terhadap beliefs siswa, artinya bagaimana pembelajaran matematika yang dilakukan oleh guru, mempengaruhi beliefs siswa terhadap matematika. Siswa yang memiliki beliefs tentang pentingnya matematika akan menimbulkan 
motivasi yang kuat, sementara siswa yang memiliki beliefs rendah, mereka tidak termotivasi dalam belajar matematika. Penelitian ini dilakukan oleh De Corte \& Eynde (2002). Penelitian lain oleh Breiteig, Grevholm \& Kislenko (2005) mengungkapkan bahwa: 1). 96\% siswa setuju bahwa matematika berguna untuk kehidupan dan $100 \%$ setuju bahwa matematika adalah penting; 2). 52\% klaim bahwa matematika membosankan, sedangkan $88 \%$ yakin bahwa mereka perlu untuk mengetahui matematika; 3 ). $84 \%$ siswa tidak setuju bahwa hanya ada satu jawaban yang benar dalam matematika tugas; 4). $96 \%$ berpikir bahwa penting untuk mendapatkan nilai yang baik dan $83 \%$ merasa penting untuk bekerja sama dalam kelas matematika. Walaupun sebagian siswa mengklaim bahwa matematika adalah penting, namun sangat disayangkan bahwa sekolah belum mampu mengatur pembelajaran adalah sedemikian rupa menjadi menantang dan menarik.

Hasil penelitian lanjutan yang dilakukan Kislenko (2006) menunjukkan hasil yang serupa, bahwa banyak siswa menganggap matematika merupakan pelajaran penting, namun mereka juga menganggap matematika merupakan pelajaran membosankan. Temuan dari penelitian Goldin, Rosken, \& Torner (2009) menunjukkan bahwa guru memiliki peranan penting dalam mengembangkan beliefs siswa terhadap matematika. Penelitian ini melihat bagaimana persepsi siswa terhadap matematika sebagai mata pelajaran dan permasalahan pada matematika.

\section{Metode Penelitian}

Penelitian ini dilaksanakan menggunakan metode penelitian deskripsi korelasional. Penelitian korelasi atau korelasional adalah suatu penelitian untuk mengetahui hubungan dan tingkat hubungan antara dua variabel atau lebih tanpa ada upaya untuk mempengaruhi variabel tersebut sehingga tidak terdapat manipulasi variabel. Menurut Sugiyono (2011:117) populasi merupakan wilayah generalisasi yang terdiri atas objek/subjek yang mempunyai kualitas dan karakteristik tertentu yang ditetapkan oleh peneliti untuk dipelajari dan kemudian diambil kesimpulannya. Sedangkan sampel merupakan bagian dari populasi yang mewakili populasi tersebut. Populasi pada penelitian ini adalah seluruh siswa di SMAN 1 Rambah, sedangkan sampel penelitiannya adalah satu kelas pada sekolah tersebut. Pengambilan sampel ditentukan berdasarkan purposive sampling. Pemilihan sampel didasarkan pada pertimbangan yang diperoleh dari guru dan kelas yang mendapatkan izin administratif dari pihak sekolah. Tujuan dilakukan pengambilan sampel seperti ini adalah agar penelitian dapat dilaksanakan secara efektif dan efisien terutama dalam hal pengawasan, kondisi subyek penelitian, waktu penelitian yang ditetapkan, kondisi tempat penelitian serta prosedur perizinan. Kelas yang digunakan sebagi sumber penelitian adalah kelas XII IPS 2 SMAN 1 Rambah.

Instrumen untuk mengumpulkan data pada penelitian ini disusun dalam bentuk angket/kuisioner skala beliefs matematis siswa. Pengembangan instrumen ini dilakukan melalui beberapa tahap, yaitu tahap pembuatan, revisi, dan tahap ujicoba instrumen. Uji coba instrumen dilakukan untuk melihat layak atau tidak suatu instrumen digunakan dalam penelitian. Pada penelitian ini berfokus pada pengukuran beliefs yang dibatasi pada beliefs siswa pada pendidikan matematika, yaitu: beliefs siswa terhadap matematika dan beliefs siswa terhadap masalah matematika. Kedua indikator beliefs tersebut dijabarkan dalam 29 item pernyataan. Pernyataan beliefs terhadap matematika terdiri atas 16 pernyataan dan 13 pernyataan lainnya berdasarkan indikator beliefs terhadap masalah matematika. 
Data yang dikumpulkan adalah berupa hasil persepsi mathematical beliefs siswa melalui angket/ kuisioner dan data hasil belajar matematika yang diperoleh dari guru mata pelajaran. Dari data yang diperoleh, baik berupa data angket dan data prestasi belajar matematika siswa, selanjutnya dianalisis sesuai dengan rumusan masalah yang telah ditentukan pada penelitian ini. Uji korelasi dimaksudkan untuk melihat hubungan dari dua hasil pengukuran atau dua variabel yang diteliti, untuk mengetahui derajat hubungan antara mathematical beliefs dengan prestasi belajar matematika siswa. Pada penelitian ini peneliti menggunakan teknik pearson correlation. Pengolahan data korelasi dilakukan dengan program SPSS 20. Adapun rumus korelasi pearson adalah sebagai berikut:

$$
r_{x y}=\frac{N \sum X Y-\sum X \sum Y}{\sqrt{\left[N \sum X^{2}-\left(\sum X\right)^{2}\right]\left[N \sum Y^{2}-\left(\sum Y\right)^{2}\right]}}
$$

Keterangan:

$\mathrm{r}_{\mathrm{xy}} \quad$ : Koefisien korelasi pearson

$\mathrm{X} \quad$ : Total kuadrat selisih antar rangking

Y : Total kuadrat selisih antar rangking

$\mathrm{N} \quad$ : Jumlah sampel penelitian

Dengan kriteria interpretasi koefisien korelasi sebagai berikut:

\begin{tabular}{cc}
\hline Interval Koefisien & Tingkat Hubungan \\
\hline 0.00 & Tidak ada Hubungan \\
\hline $0.01-0.199$ & Sangat rendah \\
\hline $0.20-0.399$ & Rendah \\
\hline $0.40-0.599$ & Sedang \\
\hline $0.60-0.799$ & Kuat \\
\hline $0.80-1.00$ & Sangat Kuat \\
\hline
\end{tabular}

\section{Hasil Penelitian dan Pembahasan}

Penelitian ini bertujuan untuk melihat kontribusi mathematical beliefs terhadap prestasi belajar siswa SMA dan untuk melihat persepsi siswa tentang beliefs siswa terhadap matematika sebagai mata pelajaran dan masalah matematika. Data persepsi siswa diperoleh melalui angket mathematical beliefs yang diberikan kepada siswa dan data prestasi belajar yang diperoleh dari nilai UTS dan UAS siswa pada kelas tersebut.

Untuk memperoleh informasi tentang kontribusi mathematical beliefs terhadap prestasi belajar matematika siswa, terlebih dahulu dilakukan beberapa tahap sebagai berikut:

\section{Transformasi data mathematical beliefs}

Data mathematical beliefs yang diperoleh melalui angket merupakan data ordinal. Untuk kepentingan penelitian, data tersebut ditransformasi menjadi data interval. Teknik yang digunakan untuk mentransformasi data tersebut adalah menggunakan sistem logit pada Rasch Model. Setelah data di transformasi, data tersebut dapat digunakan untuk keperluan uji selanjutnya. Sebagai prasyarat uji korelasi dan regresi untuk melihat kontribusi dan arah hubungan mathematical beliefs dan prestasi belajar matematika siswa dilakukan uji 
normalitas terhadap data persepsi siswa dan data prestasi belajar matematika siswa. Menggunakan bantuan aplikasi SPSS 20, diperoleh hasil sebagai berikut.

Tabel 1. Hasil uji normalitas data beliefs dan prestasi belajar matematika

\begin{tabular}{|ll|r|r|}
\hline & & \multicolumn{1}{c|}{ beliefs } & \multicolumn{1}{c|}{ prestasi } \\
\hline $\mathrm{N}$ & & 33 & 33 \\
Normal Parameters ${ }^{\mathrm{a}}$ & Mean & .1579 & 73.394 \\
& Std. Deviation & .08088 & 11.2505 \\
\multirow{2}{*}{ Most Extreme Differences } & Absolute & .109 & .125 \\
& Positive & .091 & .125 \\
& Negative & -.109 & -.106 \\
Kolmogorov-Smirnov Z & & .626 & .718 \\
Asymp. Sig. (2-tailed) & & .829 & .680 \\
\hline
\end{tabular}

a. Test distribution is Normal.

Interpretasi dari tabel tersebut adalah bahwa dengan taraf signifikansi 0,05 , diperoleh bahwa baik data mathematical beliefs maupun data prestasi belajar matematika siswa keduanya lebih besar dari 0,05. Artinya kedua data tersebut berdistribusi normal.

Uji prasyarat selanjutnya adalah uji linearitas, yaitu uji yang dilakukan untuk melihat kelinearan data variabel bebas dan data variabel terikat. Dengan bantuan program SPSS 20, diperoleh hasil sebagai berikut.

Tabel 2. Hasil uji linearitas data beliefs dan prestasi belajar matematika

\begin{tabular}{|lll|r|r|}
\hline & & \multicolumn{1}{c|}{ F } & \multicolumn{1}{c|}{ Sig. } \\
\hline prestasi * beliefs & Between Groups & (Combined) & .976 & .532 \\
& & Linearity & 3.391 & .088 \\
& & Deviation from Linearity & .842 & .640 \\
& & & \\
& Within Groups & & & \\
\hline
\end{tabular}

Dengan taraf signifikansi 0,05 memperlihatkan bahwa 0,64 lebih besar dari 0,05. Artinya, bahwa terdapat hubungan linear yang signifikan antara mathematical beliefs dengan prestasi belajar matematika siswa.

Karena memenuhi uji prasyarat, yaitu uji normalitas dan uji linearitas, selanjutnya dilakukan uji korelasi, untuk melihat hubungan antara variabel bebas dan variabel terikat. Hipotesis yang dirumuskan adalah sebagai berikut.

$\mathrm{H}_{0} \quad$ : Tidak terdapat hubungan yang signifikan antara mathematical beliefs dengan prestasi belajar matematika siswa.

$\mathrm{H}_{1} \quad$ : Terdapat hubungan secara signifikan antara mathematical beliefs dengan prestasi belajar matematika siswa

Dengan kriteria pengujian, $\mathrm{H}_{0}$ diterima jika signifikansi > 0,05 dan $\mathrm{H}_{0}$ ditolak jika signifikansi $<0,05$. Hasil yang diperoleh adalah sebagai berikut. 
Tabel 3. Hasil uji korelasi antara mathematical beliefs dengan prestasi belajar matematika

\begin{tabular}{|ll|r|r|}
\hline & \multicolumn{1}{|c|}{ beliefs } & \multicolumn{1}{c|}{ prestasi } \\
\hline beliefs & Pearson Correlation & 1 & .328 \\
& Sig. (2-tailed) & & .062 \\
& $\mathrm{~N}$ & 33 & 33 \\
\hline prestasi & Pearson Correlation & .328 & 1 \\
& Sig. (2-tailed) & .062 & \\
& $\mathrm{~N}$ & 33 & 33 \\
\hline
\end{tabular}

Dari tabel tersebut, terlihat bahwa nilai sig. (2-tailed) adalah 0,062 lebih besar dari taraf signifikansi 0,05 . Berdasarkan kriteria pengujian, diperoleh bahwa $\mathrm{H}_{0}$ diterima, yang artinya bahwa tidak terdapat hubungan yang signifikan antara mathematical beliefs dengan prestasi belajar matematika. Dari nilai pearson correlation diperoleh 0,328. Nilai tersebut merupakan koefisien korelasi, yang mengindikasikan bahwa tingkat hubungan antara mathematical beliefs dengan prestasi belajar matematika tergolong rendah.

Untuk mengetahui besar kontribusi dan ada tidaknya perngaruh mathematical belief terhadap prestasi belajar matematika, dilakukan uji regresi. Hasil uji regresi yang diperoleh adala sebagai berikut.

\section{Tabel 4. Hasil uji regresi model summary}

\begin{tabular}{|l|c|r|r|c|}
\hline $\begin{array}{l}\text { Mode } \\
\mathrm{I}\end{array}$ & $\mathrm{R}$ & $\mathrm{R}$ Square & $\begin{array}{c}\text { Adjusted R } \\
\text { Square }\end{array}$ & $\begin{array}{c}\text { Std. Error of } \\
\text { the Estimate }\end{array}$ \\
\hline 1 & $.328^{\mathrm{a}}$ & .108 & .079 & 10.7987 \\
\hline
\end{tabular}

Hasil tersebut menunjukkan bahwa kontribusi mathematical beliefs terhadap prestasi belajar matematika adalah sebesar 10,8 \% dan sisanya dipengaruhi oleh variabel lainnya. Kontribusi ini terbilang kecil, hal ini juga sejalan dengan hasil uji korelasi yang telah dilakukan sebelumnya, yang menunjukkan bahwa tidak ada hubungan secara signifikan antara mathematical beliefs dan prestasi belajar matematika siswa.

Hasil uji regresi lainnya dapat digunaka untuk melihat apakah terdapat pengaruh yang signifikan dari mathematical beliefs terhadap prestasi belajar matematika siswa. Dengan hipotesis yang dirumuskan sebagai berikut.

$\mathrm{H}_{0} \quad$ : Tidak terdapat pengaruhyang signifikan mathematical beliefs terhadap prestasi belajar matematika siswa.

$\mathrm{H}_{1} \quad$ : Terdapat pengaruh yang signifikan mathematical beliefs dengan prestasi belajar matematika siswa

Dengan kriteria pengujian, $\mathrm{H}_{0}$ diterima jika signifikansi > 0,05 dan $\mathrm{H}_{0}$ ditolak jika signifikansi $<0,05$. Hasil yang diperoleh adalah sebagai berikut.

Tabel 5. Hasil uji regresi

\begin{tabular}{|c|c|c|c|c|c|c|}
\hline \multirow{2}{*}{\multicolumn{2}{|c|}{ Model }} & \multicolumn{2}{|c|}{ Unstandardized Coefficients } & \multirow{2}{*}{$\begin{array}{c}\text { Standardized } \\
\text { Coefficients } \\
\text { Beta } \\
\end{array}$} & \multirow[b]{2}{*}{$\mathrm{t}$} & \multirow[b]{2}{*}{ Sig. } \\
\hline & & B & Std. Error & & & \\
\hline \multirow[t]{2}{*}{1} & (Constant) & 66.194 & 4.173 & & 15.861 & .000 \\
\hline & beliefs & 45.605 & 23.601 & .328 & 1.932 & .062 \\
\hline
\end{tabular}

a. Dependent Variable: prestasi 
Berdasarkan tabel tersebut, nilai signifikansi yang diperoleh adalah 0,062 lebih besar dari taraf signifikansi 0,05 , artinya $\mathrm{H}_{0}$ diterima. Sehingga diperoleh bahwa tidak terdapat pengaruh yang signifikan mathematical beliefs terhadap prestasi belajar matematika siswa.

\section{Pembahasan}

Hasil penelitian menunjukkan bahwa kontribusi dari mathematical beliefs terhadap prestasi belajar matematika siswa tergolong rendah, yaitu 10,8\%. Dari uji regresi juga menunjukkan bahwa mathematical beliefs tidak berpengaruh secara signifikan terhadap prestasi belajar matematika siswa. Hasil tersebut sedikit berbeda dengan teori yang telah ada. Ada beberapa hal yang dapat menjadi penyebab munculnya hasil tersebut, yaitu diantaranya:

1. Siswa masih sering mendapatkan permasalahan matematika yang sifatnya soal rutin, yaitu soal yang tidak melibatkan pemecahan masalah, sehingga walaupun siswa yang memperoleh nilai bagus pada saat UTS maupun UAS, belum tentu memiliki mathematical beliefs yang baik. Hal ini dikarenakan soal UTS dan UAS masih berupa soal rutin.

2. Mathematical beliefs dibangun dari pengalaman siswa, artinya beliefs siswa terhadap matematika tergantung dari pengalaman matematika siswa pada jenjang sebelumnya. Pengalaman tersebut dapat berupa model pembelajaran yang diterapkan, maupun bukubuku matematika yang digunakan. Pengalaman tersebut memungkinkan menjadi penyebab beliefs siswa terhadap matematika masih belum baik.

Beberapa belief yang masih belum baik dari hasil persepsi siswa yang diperoleh berdasarkan item pada kuisioner adalah sebagai berikut:

a. Soal matematika hanya dapat diselesaikan bila saya mengingat rumusnya.

Sebanyak $90 \%$ siswa menganggap bahwa matematika adalah pelajaran mengingat rumus. Mereka menganggap bahwa rumus adalah satu-satunya cara untuk menyelesaikan masalah matematika. Rumus merupakan prinsip dalam matematika, yang terdiri atas konsepkonsep matematika. Dengan memahami konsep matematika, seharusnya kita bisa menyelesaikan masalah matematika tanpa menggunakan rumus, artinya mengingat rumus bukan satu-satunya cara untuk menyelesaikan masalah matematika. Pembelajaran berbasis penemuan dapat membantu siswa dalam menemukan rumus dalam matematika, sehingga siswa memahami konsep-konsep yang membangun rumus tersebut.

b. Dalam menyelesaikan soal matematika, saya cukup mengikuti cara yang diberikan guru di depan kelas.

Sebanyak $78 \%$ siswa setuju dan sangat setuju bahwa menyelesaikan masalah matematika cukup dengan mengikuti cara yang diberikan oleh guru. Hal ini mengindikasikan bahwa siswa masih belum diajak untuk berpikir kreatif, dan mengembangkan konsep yang dimiliki dalam penyelesaian masalah. Tentu sudah seharusnya guru mulai mengajak siswanya memberikan masalah matematika berupa soal open ended maupun soal pemecahan masalah. Hal ini memungkinkan siswa untuk dapat berpikir kreatif.

c. Setiap soal matematika hanya memiliki satu jawaban yang benar

Sebanyak $81 \%$ siswa menganggap setiap soal matematika hanya memiliki satu jawaban yang benar. Jumlah tersebut memungkinkan siswa masih belum menjumpai soal-soal open ended. Mereka mengangap solusi matematika selalu tunggal. Sebaiknya siswa dilatih dengan 
soal-soal yang lebih bervariasi, sehingga pengalaman siswa membuat mathematical beliefsnya menjadi baik.

\section{Kesimpulan dan Saran}

Hasil penelitian ini menunjukkan bahwa mathematical beliefs tidak berpengaruh secara signifikan terhadap prestasi belajar matematika, dengan kontribusinya adalah sebesar 10,8\%. Hasil tersebut dipengaruhi oleh model pembelajaran, buku-buku yang digunakan dan masalah-masalah matematika yang diberikan kepada siswa. Hasil telaah persepsi siswa menunjukkan bahwa sebagian besar siswa masih menganggap bahwa matematika merupakan mata pelajaran mengingat rumus, masalah matematika dapat diselesaikan cukup dengan mengikuti cara yang digunakan oleh guru serta setiap soal matematika memiliki solusi yang tunggal. Karena beliefs siswa muncul berdasarkan pengalaman belajar siswa, hendaknya pembelajaran oleh guru mengarah kepada pembelajaran aktif yang membantu siswa dalam menemukan konsep sendiri, sehingga dapat menghilangkan anggapan-anggapan atau keyakinan yang salah terhadap matematika.

\section{Daftar Pustaka}

Breiteig, T., Grevholm, B., \& Kislenko, K. (2005). Beliefs and Attitudes in Mathematics Teaching And Learning. Vurdering i matematikk-Hvorfor og hvordan, hlm 129-138.

De Corte, E., \& Op't Eynde, P. (2002). Unraveling Students' Belief Systems Relating To Mathematics Learning and Problem Solving. In Proceedings of the International Conference "The Humanistic Renaissamce in Mathematics Education", hlm 96-101.

Djamarah, Syaiful B., dan Zain, Aswan. (2006).Strategi Belajar Mengajar, Rineka Cipta, Jakarta.

Eleftherios, K., \& Theodosios, Z. (2007). Students' Beliefs and Attitudes about Studying and Learning Mathematics. Proceedings of the 31st Conference of the International Group for the Psychology of Mathematics Education, 3, hlm 97-104.

Hudojo, H., 1990, Strategi Belajar Mengajar Matematika, IKIP Malang, Malang.

Kislenko, K. (2006). Structuring Students' Beliefs in Mathematics: A Norwegian Case. In Current State of Research on Mathematical Beliefs XII Proceedings of the MAVI-12 Workshop, hlm 1-10.

Kloosterman, P \& Stage, F, K. (1992). Measuring Beliefs about Mathematical Problem Solving. School Science and Mathematics Academic Research Library. hlm 109.

NCTM. (2000). Principles Standards and For School Mathematics. United States of America: The National Council of Teachers of Mathematics, Inc.

OECD. (2013). PISA 2012 Assessment and Analytical Framework: Mathematics, Reading, Science, Problem Solving and Financial Literacy. OECD Publishing.

Spangler, D. A. (1992). Assessing Students' Beliefs about Mathematics. Arithmetic Teacher, 40, hlm 148-148. 
Sudjana, Nana., 2010, Dasar-Dasar Proses Belajar Mengajar, Sinar Baru Algesindo, Bandung.

Sugiyono. (2011). Metode Penelitian Pendidikan Pendekatan Kuantitatif, Kualitatif, Dan $R \& D$. Bandung: Alfabeta.

Sugiman. (2010). Dampak Pembelajaran Matematika Realistik Terhadap Peningkatan Kemampuan Pemecahan Masalah Dan Keyakinan Matematik Siswa Sekolah Menengah Pertama Di Kota Yogyakarta. (Disertasi). Sekolah Pascasarjana, Universitas Pendidikan Indonesia, Bandung. 